\title{
IMPACT OF LIGHT AND DARK ON VERTICAL MIGRATIONS OF VERTIGO MOULINSIANA (DUPUY, 1849) (GASTROPODA: EUPULMONATA: VERTIGINIDAE)
}

\author{
NATALIA CEBULKA, BARTŁOMIEJ GOŁDYN, ZOFIA KsiĄŻKIEWICZ-PARULSKA*
}

\begin{abstract}
Department of General Zoology, Adam Mickiewicz University, Uniwersytetu Poznańskiego 6, 61-614 Poznań, Polska (e-mails: n.cebulka@gmail.com, glodny@amu.edu.pl,ksiazkiewicz@amu.edu.pl); BG ำ https://orcid.org/0000-0002-5470-6709; ZKP ๑ https://orcid.org/0000-0001-9271-6599 *corresponding author
\end{abstract}

ABSTRACT: We investigated vertical migration distances of Vertigo moulinsiana (Dupuy) in conditions of (1) 24-hour illumination and (2) 24-hour darkness. The experiments were carried out in the laboratory, at high and constant humidity (RH 100\%), and $22{ }^{\circ} \mathrm{C}$ temperature. The snails were placed singly in $150 \mathrm{~cm}$ long, vertically oriented transparent plastic tubes (inner diameter: $8 \mathrm{~mm}$ ). The tubes for the dark experimental variant were covered with aluminum foil, while those for the light variant were evenly illuminated with cold light lamps. A One-Way ANOVA showed that the snails from the $24 \mathrm{~h}$ light variant climbed up higher than those kept in the darkness, regardless on the age group.

KEY WORDS: behaviour; laboratory experiments; Gastropoda; diurnal activity

\section{INTRODUCTION}

Factors triggering vertical migrations have been described for some land snail species (e.g. COWIE 1985, PODROUŽKOVÁ et al. 2015), but little is known about factors affecting the distances of these movements. Vertigo moulinsiana (Dupuy, 1849) is found over a large vertical range, attached to monocot plants up to $2 \mathrm{~m}$ above the ground (KILLEEN 2003). The species is hygrophilous and occurs in habitats where water levels may raise above the ground surface (e.g. POKRYSZKO 1990, KILLEEN 2003). Thus it is suspected that the vertical migration behaviour may be an adaptation to life in temporarily flooded areas (KSIĄŻKIEWICZ-PARULSKA 2019). In this study we focused on factors which may affect the vertical migration distances of $V$. moulinsiana. We studied the possible dependence between these movements and the presence of light: we checked to what height the snails climbed when exposed to 24-hour illumination and 24-hour darkness.

\section{MATERIAL AND METHODS}

In the experiment we used representatives of two age groups: adults and juveniles (shells of maximum of 2 whorls); 30 individuals in each experimental variant (15 adults and 15 juveniles for each variant; in total 60 snails). Since $V$. moulinsiana is strictly protected in Poland and listed in Annex II of the European Commission's Habitats Directive (92/43/EEC), the snails used in the experiments were obtained from a captive breeding stock. The founder individuals were derived from a locality in northwestern Poland (for details see KSIĄŻKIEWICZ-PARULSKA \& PAWLAK 2016); for the experiment we used the second-generation snails.

For 10 days preceding the experiment, the individuals were kept separately in ventilated plastic cups (diameter: $4 \mathrm{~cm}$, height: $6.5 \mathrm{~cm}$ ) with damp cot- 
ton pads, decaying sedge material (derived from the original locality) as a source of food, and dolomite dust as a source of calcium. The snails were gently sprinkled with water once a day or every two days (depending on the needs) to maintain high humidity. The cups were kept in a transparent plastic box as a protection against desiccation. The temperature in the rearing room was $22^{\circ} \mathrm{C}$; the snails were kept under natural photoperiod.

To check the distances of vertical migrations (i.e. to what height $V$. moulinsiana climbs up) in the dark and light conditions, we used sixty $150 \mathrm{~cm}$ long, vertically oriented, transparent plastic tubes (inner diameter: $8 \mathrm{~mm}$ ). Shortly before the experiment started, all 60 tubes were rinsed with water and plugged at the top with water-saturated cotton-wool. This procedure was applied to maintain high humidity conditions inside the tubes (at or near $100 \%$ with condensation on the sides of the tubes). Then, the tubes were (1) covered with aluminum foil for the dark variant (30 tubes) or (2) evenly illuminated

\section{RESULTS}

Statistical analyses showed significant differences between the vertical migration distance in adults ( $F$ $=12.250, \mathrm{p}=0.002)$ and juveniles $(\mathrm{F}=4.612, \mathrm{p}=$ 0.033) depending on the light conditions. Both juveniles and adults were found higher in the samples which were illuminated than in the dark conditions

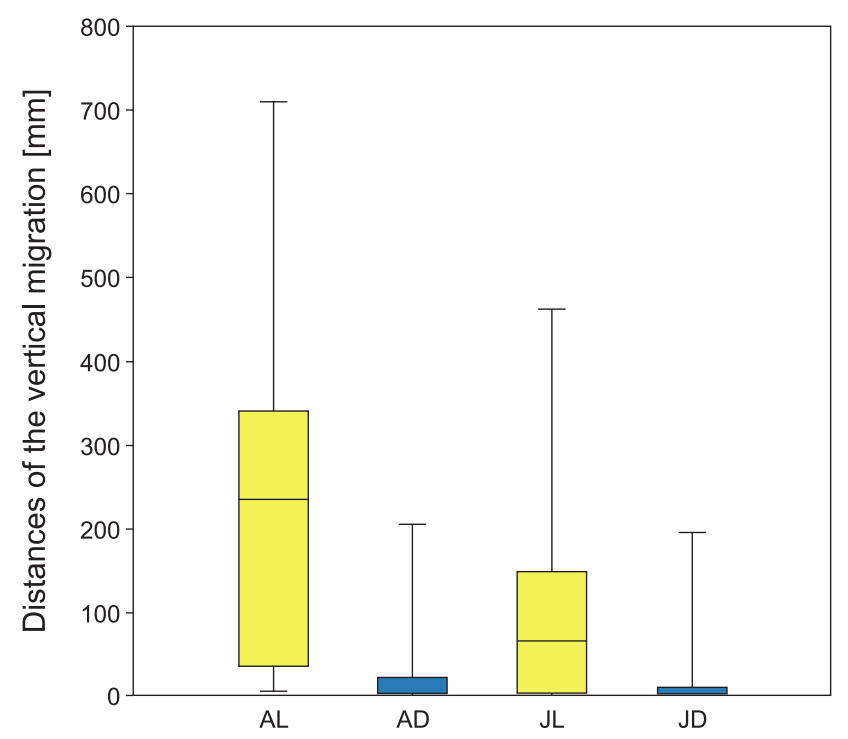

\section{DISCUSSION}

The experiment shows that exposure to light and dark affects differently the vertical migration behaviour of $V$. moulinsiana. When illuminated, the snails, regardless of the studied age group, migrate for great- with non-heat emitting lamps (daylight LED tube - AQUAEL 6W) for the light variant (remaining 30 tubes). Each snail was individually placed in the tube on the water-saturated cotton-wool plug of the tube bottom. The observations were carried out in the rearing room, at the same temperature as in pre-experimental conditions (at $22^{\circ} \mathrm{C}$ ).

The snails were exposed to experimental conditions for 24 hours. After this time, the distances of vertical migration inside the tube were measured from the cotton-wool inner surface to the place where the snail was attached. In the course of the experiment five snails died (two adults from dark variant and three juveniles: one from light variant and two from dark variant). Thus in the further analyses we used 15 adults and 14 juveniles for the light variant and 13 adults and 13 juveniles for the dark variant. Since the data distribution was far from normal, we used randomised One-Way ANOVA to analyse the data (JADWISZCZAK 2009). For data visualisation we used Past software (HAMMER 2020).

(Fig. 1). On the other hand, the vertical migration distance showed no statistically significant differences between adults and juveniles kept at the same conditions (adults and juveniles in light conditions: $\mathrm{F}=3.933 ; \mathrm{p}=0.062$; adults and juveniles in dark conditions: $\mathrm{F}=0.142 ; \mathrm{p}=0.599)$.

Fig. 1. Distances of the vertical migration of Vertigo moulinsiana: light conditions (yellow bars) for adults (AL) and juveniles (JL); dark conditions (blue bars) for adults (AD) and juveniles (JD). Horizontal line inside the box - median; minimum and maximum values - whiskers

er distances than in the dark. It seems that the light exposure, at high humidity conditions, stimulates vertical migrations in $V$. moulinsiana. The previous studies on light-dark cycle have shown that both ju- 
veniles and adults of $V$. moulinsiana are more active at night than during the day (KSIĄŻKIEWICZ-PARULSKA 2018). Combining these observations with conclusions of the present study, it seems that the overall activity does not reflect the total distances of vertical migrations. Nocturnal movements would then be less directional and possibly associated with more or less developed homing behaviour. On the contrary, directional migrations observed under constant, intense illumination could reflect stress avoidance. In natural conditions light implies an increasing water loss due to sun-derived-heat. Therefore, the greater migration distances under light conditions observed in this study may be the effect of active search for shelter which is less exposed to light. Finally, it cannot be excluded that in the highly artificial laboratory conditions the snail behaviour differs substantially from that in the natural habitat.

\section{REFERENCES}

COWIE R. H. 1985. Microhabitat choice and high temperature tolerance in the land snail Theba pisana (Mollusca: Gastropoda). Journal of Zoology 207: 201-211. https:// doi.org/10.1111/j.1469-7998.1985.tb04924.x

HAMmER Ø. 2020. PAST4. PAleontological STatistics. Available on-line at http://folk.uio.no/ohammer/past/ (accessed 30 March 2020).

JADWISZCZAK P. 2009. Random Pro 3.14. Software for classical and computer-intensive statistics. Available on-line at http://pjadw.tripod.com (accessed 15 November 2016).

KILLEEN I. J. 2003. Ecology of Desmoulin's whorl snail. Conserving Natura 2000 Rivers Ecology Series, No.6. English Nature, Peterborough.

KSIĄŻKIEWICZ-PARULSKA Z. 2018. The light-dark cycle of Desmoulin's whorl snail Vertigo moulinsiana Dupuy 1849 (Gastropoda, Pulmonata, Vertiginidae) and its activity patterns at different temperatures. Animal Biodiversity and Conservation 41: 109-115. https:// doi.org/10.32800/abc.2018.41.0109
Concluding, it seems that vertical migrations in $V$. moulinsiana may be affected by external conditions such as light and darkness. However, further studies are needed to learn more about the character of this behaviour. Since $V$. moulinsiana spends most of the year on plants (including winter), and is found in great numbers in the litter only in spring (the species probably descends toward the litter to lay eggs; KSIĄŻKIEWICZ-PARULSKA 2019) it may be suspected that the photoperiod affects this behaviour. It should be also checked if the intensity of vertical migrations changes diurnally and relates to the temperature and moisture variations.

\section{ACKNOWLEDGEMENTS}

We thank the anonymous reviewer for the valuable comments.

KSIĄŻKIEWICZ-PARULSKA Z. 2019. Vertical migrations in two hygrophilous species of micro-snails in relation to time of the year and habitat type. Invertebrate Biology 138: e12253. https://doi.org/10.1111/ivb.12253

KSIĄŻKIEWICZ-PARULSKA Z., PAWLAK K. 2016. Rare species of micromolluscs on the city of Poznan (W. Poland) with some notes on wintering of Vertigo moulinsiana (Dupuy, 1849). Folia Malacologica 24: 97-101. https:// doi.org/10.12657/folmal.024.007

PODROUŽKOVÁ Š., JANOVSKÝ Z., HORÁČKOVÁ J., JUŘIČKOVÁ L. 2015. Do snails eat exotic plant species invading river floodplains? Journal of Molluscan Studies 81: 139-146. https://doi.org/10.1093/mollus/eyu073

PokRYSZKO B. M. 1990. The Vertinigidae of Poland (Gastropoda: Pulmonata: Pupilloidea) - a systematic monograph. Annales Zoologici 43: 134-257.

Received: May 27th, 2020

Revised: June 26th, 2020

Accepted: June 30th, 2020

Published on-line: July 14th, 2020 